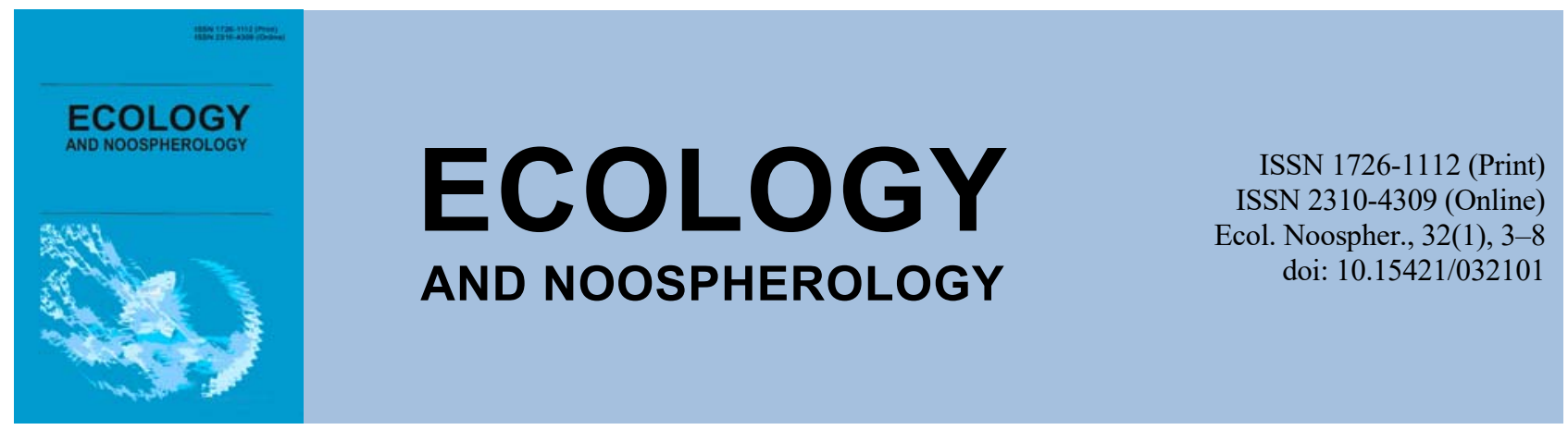

\title{
Comparative analysis of the antioxidant capacity and secondary metabolites accumulation in the fruits of rowan (Sorbus aucuparia L.) and some closely related species
}

\author{
Y. V. Lykholat, O. O. Didur, N. O. Khromykh, V. R. Davydov, \\ Y. S. Borodai, K. V. Kravchuk, T. Y. Lykholat
}

Oles Honchar Dnipro National University, Dnipro, Ukraine

\begin{tabular}{l} 
Article info \\
Received 18.03.2021 \\
Received in revised form \\
\multicolumn{1}{c}{26.03 .2021} \\
Accepted 11.04.2021 \\
Oles Honchar Dnipro \\
National University, \\
Gagarin Ave., 72, Dnipro, \\
49010, Ukraine. \\
Tel.: +38-050-454-97-33 \\
E-mail: didur@ua.fm
\end{tabular}

Lykholat, Y. V., Didur, O. O., Khromykh, N. O., Davydov, V. R., Borodai, Y. S., Kravchuk, K. V., Lykholat, T. Y. (2021). Comparative analysis of the antioxidant capacity and secondary metabolites accumulation in the fruits of rowan (Sorbus aucuparia L.) and some closely related species. Ecology and Noospherology, 32(1), 3-8. doi:10.15421/032101

The paper presents the results of studying fruits antioxidant properties of several species, previously combined into the genus Sorbus L. (Rosaceae family). Ripe fruits were collected in September 2020 from the plants of Cormus domestica (L.) Spach, Sorbus aucuparia L., Karpatiosorbus latifolia (Lam.) Sennikov \& Kurtto and Torminalis glaberrima (Gand.) Sennikov \& Kurtto from the collection of the Botanical Garden of the Oles Honchar Dnipro National University. Total phenolic content (TPC), total flavonoids content (TFC), ferric reducing antioxidant power (FRAP) and total antioxidant capacity (TAC) were determined both in the fruits peel and pulp. In the fruits of all species, higher values of the determined indicators were found in the fruit peel than in the pulp. Moderate and strong positive correlation was found between FRAP and TPC as well between FRAP and TFC both in peel and pulp of all studied species. At the same time, notable interspecific differences of the phytochemical traits were established, indirectly confirming the ambiguity of the taxonomy of the genus Sorbus L. According to the fruits antioxidant properties and secondary metabolites accumulation, species $K$. latifolia (broad-leaved whitebeam) and T. glaberrima (wild service-tree) are the most promising for cultivation in arid conditions of the central steppe of Ukraine.

Keywords: genus Sorbus; rowans; biologically active compounds in fruits; phenolic compounds; flavonoids; ferric reducing antioxidant power; total antioxidant capacity

\section{Introduction}

Fruit plants have always been one of the most important nutrition sources for humans. The nutritional benefits of products determine their consumer value and competitiveness. In the modern world, there is a trend towards the elimination of synthetic compounds from food and the use of natural plant extracts. In the food market, plant extracts have won a leading position due to the fact that they have the highest antioxidant potentials. The most valuable are the extracts of medicinal plants, which, in addition to compounds with antioxidant properties, contain other biologically important substances (Dragonyuk et al., 2012).

The steppe zone of Ukraine is characterized by a limited species composition and insufficient distribution of autochthonous fruit plants. In this regard, the introduction of productive cultivated species from other geographic regions can enrich the spectrum of fruit species. Today, among the underutilized fruit plants in Ukraine, there are representatives of the genus Sorbus L. (Grynyk et al., 2019). Meanwhile, plants of this genus have unique medicinal properties due to the high content of biologically active secondary metabolites in both vegetative and generative organs (Gaivelyte et al., 2013; Zymone et al., 2018). The beginning of species of the genus Sorbus cultivation in Ukraine dates back to 1809 , and by 1999 , 14 species were introduced into the culture (Melnichenko, 1999).

The genus Sorbus L. (rowan) sensu lato is highly diverse, including more than 250 species of trees and shrubs that grow naturally in East Asia and are widespread in the Northern Hemisphere under different climatic and ecological conditions (Soltys et al., 2020). The genus Sorbus is a typical example of a genus with a complex and disordered taxonomy, which today is far from an unambiguous solution. In this regard, the taxonomic status of many of the described mountain ash species is constantly being refined. According to Datsko (2004), the composition of the genus Sorbus L. sensu stricto includes from 50 to 84 species, while Sołtys et al. (2020) indicate 88 species. According to a number of researchers, the description of new taxa on the European continent is due to the exceptional genetic and morphological diversity within the 
genus, which is the result of repeated polyploidization, homoand heteroploid hybridization, backcrossing and apomixis (Welk et al., 2016; Tomović et al., 2020). For example, hybrids between Sorbus torminalis (L.) Crantz and Sorbus aria are widespread in central and western Europe, as well as in the eastern part of Crimea. As a rule, it is very difficult or practically impossible to define the boundaries of these taxa, which is why they are often called Sorbus latifolia agg. (Zieliński \& Vladimirov, 2013).

Despite the taxonomic complexity of the genus Sorbus L. sensu lato, in recent years, the number of studies of phytochemical compounds, antioxidant potential and biological activity of rowan fruits, as well as taxa previously included in the genus Sorbus L. The data obtained support the characterization of rowan fruits as "superfruits" containing various phytochemicals, including phenolic acids, flavonoids, proanthocyanidins, iridoids, coumarins, hydrolysable tannins, carotenoids, and anthocyanins (Chang et al., 2019). Research results indicate prospects for expanding the use of plant extracts in natural medicines, cosmetics and as innovative food ingredients that may find wider application in functional foods (Sarv et al., 2020). However, according to Olszewska et al. (2010), today most species of the genus Sorbus L. are not phytochemically characterized, with the exception of a few species with known ethno medical significance, such as S. aucuparia L., S. americana Marsh., S. cashmiriana Hedl., S. commixta Hedl. and S. decora (Sarg.) C.K. Schneid. The analysis of scientific literature, carried out by these authors, indicates that indicated species have antioxidant, antiatherogenic, anti-inflammatory, antidiabetic, vasoprotective and vasodilatory effects. Most of the biological activity of the studied rowan species is associated with the presence of phenolic components.

Studies carried out by Olszewska (2011) showed that Sorbus aucuparia L. leaf extracts are universal antioxidants and revealed a strong correlation between antioxidant potential and total phenol content. The best antioxidant properties and the highest phenolic content were found in leaves harvested during the three summer months (June, July and August). Raudone et al. (2015) found that the leaves of the species Sorbus commixta Hedl., Sorbus discolor (Maxim.) Maxim. and Sorbus gracilis (Siebold \& Zucc.) K. Koch have higher antioxidant activity in comparison with the species Hedlundia anglica (Hedl.) Sennikov \& Kurtto, Sorbus aria Linnaeus, 1753, Sorbus austriaca Gruppe, Hedlundia armeniaca (Hedl.) Mezhenskyj $\times$ hostii (Jacq.ex Host) Sennikov \& Kurtto, as well as Karpatiosorbus semiincisa (Borbás) Sennikov \& Kurtto, Sorbus tianschanica Rupr.).

The study of phenolic and antioxidant profiles of fruits of different Sorbus species showed that neochlorogenic and chlorogenic acids are markers of antioxidant activity (Raudonis et al., 2014). In particular, the fruits of the Sorbus commixta Hedl. contain a number of active compounds, including chlorogenic acid, rutin, protocatechic acid, hydroxybenzoic acid, which are known to have anti-cancer activity (Jin et al., 2020).

A number of researchers have shown the multidisciplinary beneficial medical effects of extracts from the cortex of Sorbus commixta Hedl. Thus, water and ethanol extracts from the cortex of S. commixta suppress inflammatory processes and can be useful for patients with asthma, bronchitis, gastritis (Yu et al., 2009, 2011). Ethanol extracts from the S. commixta cortex have a photoprotective effect against the negative effects of ultraviolet radiation on the skin (Bae et al., 2007). Methanol extracts of S. commixta cortex are antitoxic (Lee et al., 2006); methanol and butanol extracts have vasodilating properties (Kang et al., 2005; Yin et al., 2005) and also exhibit antiatherogenic effects (Sohn, 2005a, 2005b).

Thus, the scientific data available today indicate a rich phytochemical composition and a high antioxidant capacity of the Sorbus plants and species previously attributed to this genus, including those that were introduced in the steppe zone of Ukraine. However, even the successful acclimatization of alien plants species and varieties does not guarantee a consistently high yield, as well as the nutritional and biological value of fruit plant products. One of the reasons lies in the natural variability of the plant chemical composition, reflecting the degree of realization of the genetic potential of plant species under certain environmental conditions. The purpose of our work was to study the antioxidant properties of the fruits Sorbus aucuparia L., Cormus domestica (L.) Spach, Karpatiosorbus latifolia (Lam.) Sennikov \& Kurtto and Torminalis glaberrima (Gand.) Sennikov \& Kurtto, growing in the arid conditions of the steppe zone of Ukraine, and to assess the prospects of different species for distribution in the region.

\section{Material and methods}

Fruits of different species previously assigned to the genus Sorbus L., namely, Cormus domestica (L.) Spach, Sorbus aucuparia L., Karpatiosorbus latifolia (Lam.) Sennikov \& Kurtto, and Torminalis glaberrima (Gand.) Sennikov \& Kurtto, were used for a comparative assessment of the plants antioxidant potential. Ripe fruits were collected in late September - early October 2020 on the territory Botanical Garden of Oles Honchar Dnipro National University ( $48^{\circ} 26^{\prime} 7$ "N $35^{\circ} 2^{\prime} 34^{\prime \prime}$ E, Dnipro city, Ukraine). Plant species are named according to Synonymic Checklists of the Vascular Plants of the World (https://www.gbif.org/ru/dataset/688b94022cd6-4c87-aed3-c36246812731).

Cormus domestica (L.) Spach (syn. Sorbus domestica L.) is a rare wild tree with deciduous nature, 15-20 (rarely 30 ) m tall with broad. Service tree grows slowly (except in the juvenile period), reaches the age of 200-300 years and prefers warm and mild climate. It does not require any specific soil properties, but it grows well on deep and fertile soils. It can withstand drought, but is sensitive to late spring frosts. In a forest ecosystem, the ecological significance of this tree is great due to the forage (fruits) which it offers to wildlife species. Furthermore, its timber is valuable due to its excellent aesthetic and technical characteristics (Drvodelić et al., 2018). Distribution areal of C. domestica extends to North Africa and Asia Minor, but this species also can be found in Central Europe (Poljak et al., 2015), Romania and Crimea Mt. (Paganová, 2008). The C. domestica trees grow mainly in the oak forests in these locations and in forest-steppe stands; it even thrives in locations that have a negative water balance during the growing season (Poljak et al., 2015). Several seedlings of Cormus domestica (L.) Spach were planted in the DNU Botanical Garden in 1958.

Plants of Sorbus aucuparia L. (European mountain-ash, Mountain ash) species are trees with an average height of 10 $20 \mathrm{~m}$, maximum $27 \mathrm{~m}$; however, they grow like bushes on the almost bare rocky cliffs. It is a light-loving pioneer tree with fast growth, reaching a maximum age of 80 to 100 years (Burga et al., 2019). S. aucuparia is widespread in Europe from sea level to the timberline and reaches its most northern range in Norway at $71^{\circ} \mathrm{N}$. Plants of S. aucuparia occurs on dry to moist and mesotrophic to oligotrophic soils. Bozhuyuk et al. (2020) reported that S. aucuparia plants were found in European countries, Caucasia and Siberia. In Ukraine, common mountain ash (S. aucuparia) grows in natural conditions, and is also widely cultivated as a valuable fruit, medicinal and ornamental plant. The main biologically active substances of rowan fruits are phenolic compounds, terpenoids, organic acids, carbohydrates and vitamins, which cause a diuretic, choleretic, antioxidant, anti-inflammatory and hemostatic effect (Markin \& Krivoruchko, 2020). In the Botanical Garden of the DNU named after Oles Honchar, plants of the species S. aucuparia have been growing since 1952 .

Torminalis glaberrima (Gand.) Sennikov \& Kurtto (syn. Sorbus torminalis (L.) Crantz) plants are the trees with a height of 10-25 m (maximum $32 \mathrm{~m}$ ) and a trunk diameter of 15$75 \mathrm{~cm}$ (up to $1 \mathrm{~m}$ ). This species has high ecological plasticity, shows resistance to soil and air drought, is tolerant to the 
degree of soil moisture and is not inferior to common oak (Quercus robur L.), since it evaporates much less moisture when grown in arid conditions. According to Thomas et al. (2017), T. glaberrima is widely distributed throughout lower elevation temperate and Mediterranean zones of Europe, extending eastwards into the Caucasus Mountains and northern Iran. In the south, it extends into the Iberian Peninsula, and Morocco and Algeria in north-west Africa in the west, and into eastern Syria and Lebanon in the east. In the north, it extends to the Baltic and is largely absent from Scandinavia except for Denmark. T. glaberrima is a native species in the western part of Ukraine, where the extreme northeastern border of its distribution lies (Grynyk et al., 2019). Today this species is included in the Red Data Book of Ukraine (Red data book, 2009). On the territory of the Botanical Garden of the DNU named after Oles Honchar T. glaberrima has been grown since 1958.

Karpatiosorbus latifolia (Lam.) Sennikov \& Kurtto (syn. Sorbus latifolia (Lam.) Pers.) is a complex of hybridogeneous forms between Sorbus aria (L.) Crantz and Sorbus torminalis (L.) Crantz (Rudow \& Aas, 1997; Feulner et al., 2013). These plants grow as shrubs or almost as small trees. Leaves simple, variably whitish- to greyish- or greenishtomentose underneath, with 7-12 pairs of lateral veins, with small to prominent, rather acute lobes, with a variable number of teeth. Petals white; fruits are rather big, yellowish-, orange-, reddish-brown, with numerous large lenticels (Sennikov \& Kurtto, 2017). Plants of $K$. latifolia are in the collection of Botanical Garden of DNU since 1952.

Plant isopropanol extracts of fruit peel and pulp containing the phenolic compounds were obtained as previously described (Khromykh et al., 2018). The Folin - Ciocalteau method (Singleton et al., 1999) in slight modification was used for the total phenolic content (TPC) measurement, followed by the results were calculated using a calibration graph prepared on the solutions of Gallic acid (GA), and expressed as mg GA equivalents per $100 \mathrm{~g}$ of wet weight (mg GA/100 g WW). Total flavonoids content (TFC) in fruit peel and pulp was determined by aluminum chloride spectrophotometric method (Pękal \& Pyrzynska, 2014) and expressed as mg Rutin Equivalents per $100 \mathrm{~g}$ of plant (mg Ru/100 g WW). Ferric reducing antioxidant power (FRAP) of the plant extracts was evaluated using potassium ferricyanide method (Pulido et al., 2000) and was expressed in $\mathrm{mg}$ Ascorbic Acid per $\mathrm{g}$ plant material (mg AA/100 g WW). Evaluation of total antioxidant capacity (TAC) of fruit peel and pulp was carry out in accordance with Prieto et al (2000) using the reagent solution ( $0.6 \mathrm{M}$ sulfuric acid, $28 \mathrm{mM}$ sodium phosphate, and $4 \mathrm{mM}$ ammonium molybdate); the results were calculated using a calibration graph prepared on the solutions of Ascorbic Acid, and expressed as mg AA per $100 \mathrm{~g}$ of plant material (mg AA/100 $\mathrm{g} \mathrm{WW}$ ).

The content of secondary metabolites in fruits of mountain ash and closely related species was assessed statistically by calculating the mean content and standard error. The Tukey's HSD test was used to compare the mean values of the studied parameters (TPC, PFC, FRAP and TAC) in the skin and pulp of rowan fruits. The relationship between the phytochemical characteristics of the skin and fruit pulp was assessed by the Pearson correlation coefficient.

\section{Results and discussion}

The study of the processes of secondary metabolites accumulation revealed significant differences both in dynamics and the level of accumulation in the peel and pulp of fruits of various cultivated plant species (Shaposhnik et al., 2011), which was taken into account in our study. According to the results of determining the phytochemical parameters of rowan fruits and closely related species, statistically significant differences were found in the total content of phenolic compounds (TPC) in the peel and pulp of fruits (Table 1). The highest level of Total phenols for fruit pulp was found in the species Torminalis glaberrima (308.6 mg GA / 100 g), which exceeds the values for other species by 2.0-2.3 times. In the skin of fruits, the maximum level of Total phenols content, characteristic of Karpatiosorbus latifolia (493.3 mg GA / 100 g), was 1.4-2.0 times higher than the level of all other studied species.

Table 1

Statistical differences of total phenolic content (TPC, mg GA/100 g) in the fruits of rowan and closely related species $(\mathrm{X} \pm \mathrm{SE}, n=3, \mathrm{P}<0.05)$

\begin{tabular}{lcc}
\hline \multicolumn{1}{c}{ Species } & Pulp & Peel \\
\hline S. aucuparia & $158.9 \pm 2.68^{\mathrm{a}}$ & $361.7 \pm 9.67^{\mathrm{a}}$ \\
K. latifolia & $162.9 \pm 2.68^{\mathrm{a}}$ & $493.3 \pm 1.52^{\mathrm{b}}$ \\
C. domestica & $135.6 \pm 4.41^{\mathrm{a}}$ & $251.9 \pm 1.52^{\mathrm{c}}$ \\
T. glaberrima & $308.6 \pm 10.71^{\mathrm{b}}$ & $250.4 \pm 6.95^{\mathrm{c}}$ \\
\hline
\end{tabular}

Note: the different letters in column indicate statistically significant differences in the means of the compared pair according to the Tukey criterion (HSD).

The variability of the total content of flavonoids (TFC) in fruits of different rowan species (Table 2) had patterns similar to those for total phenols content. In the fruit pulp, the maximum flavonoids content was established for the species Torminalis glaberrima (49.3 $\mathrm{mg} \mathrm{Ru} / 100 \mathrm{~g}$ ), which is $2.3-3.0$ times higher than that of all other species. In the skin of fruits, the total content of flavonoids in the species Karpatiosorbus latifolia (104.5 mg Ru / $100 \mathrm{~g}$ ) exceeds the level of accumulation in other species by $1.2-1.8$ times.

\section{Table 2}

Statistical differences of total flavonoids content (TFC, $\mathrm{mg} \mathrm{Ru} / 100 \mathrm{~g}$ ) in the fruits of rowan and closely related species $(\mathrm{X} \pm \mathrm{SE}, n=3, \mathrm{P}<0.05)$

\begin{tabular}{lcc}
\hline \multicolumn{1}{c}{ Species } & Pulp & Peel \\
\hline S. aucuparia & $16.27 \pm 1.04^{\mathrm{a}}$ & $85.08 \pm 1.08^{\mathrm{a}}$ \\
K. latifolia & $21.54 \pm 1.10^{\mathrm{a}}$ & $104.47 \pm 1.24^{\mathrm{b}}$ \\
C. domestica & $17.95 \pm 1.10^{\mathrm{a}}$ & $58.52 \pm 1.29^{\mathrm{c}}$ \\
T. glaberrima & $49.30 \pm 1.46^{\mathrm{b}}$ & $56.72 \pm 1.56^{\mathrm{c}}$ \\
\hline
\end{tabular}

Note: the different letters in column indicate statistically significant differences in the means of the compared pair according to the Tukey criterion (HSD).

The antioxidant capacity of rowan fruit, defined as Ferric reducing antioxidant power (FRAP) in the pulp and peel of the fruit (Table 3), varied in accordance with the trends previously established for TPC and TFC. The level of FRAP in fruit pulp found in the species Torminalis glaberrima (355.0 mg AA / $100 \mathrm{~g}$ ) was 1.3-1.9 times higher than in other studied species. The FRAP value in the peel of Karpatiosorbus latifolia fruits (674.6 mg AA / $100 \mathrm{~g}$ ) is the maximum, exceeding the values of other species by 1.1-1.6 times.

\section{Table 3}

Statistical differences of FRAP (mg AA/100 g) in the fruits of rowan and closely related species $(\mathrm{X} \pm \mathrm{SE}, n=3, \mathrm{P}<0.05)$

\begin{tabular}{lcc}
\hline Species & Pulp & Peel \\
\hline S. aucuparia & $183.1 \pm 6.33^{\mathrm{a}}$ & $561.4 \pm 7.85^{\mathrm{a}}$ \\
K. latifolia & $277.8 \pm 4.44^{\mathrm{b}}$ & $674.6 \pm 9.98^{\mathrm{b}}$ \\
C. domestica & $209.1 \pm 6.05^{\mathrm{a}}$ & $592.8 \pm 8.25^{\mathrm{a}}$ \\
T. glaberrima & $355.0 \pm 11.00^{\mathrm{c}}$ & $433.1 \pm 9.98^{\mathrm{c}}$ \\
\hline
\end{tabular}

Note: the different letters in column indicate statistically significant differences in the means of the compared pair according to the Tukey criterion (HSD).

At the same time, the distribution of the total antioxidant activity (TAC) in the skin and pulp of rowan fruits was not similar to the previous indicators (Table 4). In the fruit pulp, the highest TAS level established for the species Cormus domestica (571.0 mg AA/100 g) was significantly higher only 
than the indicator for the species Sorbus aucuparia (1.9 times) and slightly differed from the levels of other species. For the skin, the highest TAC level in the fruits of Torminalis glaberrima (947.4 mg AA/100 g) statistically significantly exceeds the indicators of all other species (1.4-2.0 times).

\section{Table 4}

Statistical differences of total antioxidant capacity (TAC, mg AA/100 g) in the fruits of rowan and closely related species $(\mathrm{X} \pm \mathrm{SE}, n=3, \mathrm{P}<0.05)$

\begin{tabular}{lcc}
\hline \multicolumn{1}{c}{ Species } & Pulp & Peel \\
\hline S. aucuparia & $307.5 \pm 10.87^{\mathrm{a}}$ & $473.7 \pm 17.47^{\mathrm{a}}$ \\
K. latifolia & $539.6 \pm 14.49^{\mathrm{b}}$ & $699.6 \pm 21.96^{\mathrm{b}}$ \\
C. domestica & $571.0 \pm 9.58^{\mathrm{b}}$ & $668.2 \pm 16.30^{\mathrm{b}}$ \\
T. glaberrima & $529.2 \pm 2.09^{\mathrm{b}}$ & $947.4 \pm 11.31^{\mathrm{c}}$ \\
\hline
\end{tabular}

Note: the different letters in column indicate statistically significant differences in the means of the compared pair according to the Tukey criterion (HSD).
Analysis of the levels of accumulation of secondary metabolites in the skin and pulp of fruits (Fig. 1) showed that for the species Torminalis glaberrima this ratio is close to unity (1.16 for TPC; 0.87 for TFC, and 0.82 for FRAP). Similar ratios in other species were more variable, with the exception of the ratio of TAC indicators, which is also close to unity.

It is known that the antioxidant system of plants is one of the important nonspecific mechanisms of resistance, which significantly contribute to the drought resistance of plants (Kolupaev \& Kokorev, 2019). Obviously, in an arid steppe climate, the advantage will be on the side of plants with a high level of functioning of the antioxidant system. Comparative analysis of the total (peel and pulp) characteristics of the fruits of the studied rowan species allows us to select the species Karpatiosorbus latifolia as the most promising for distribution in the region, since the fruits of this species have the maximum levels of phytochemical indicators (Table 5). Torminalis glaberrima can also be included in a number of promising species, since the TAC level of this species fruits exceeds that of the Sorbus aucuparia and Cormus domestica fruits.

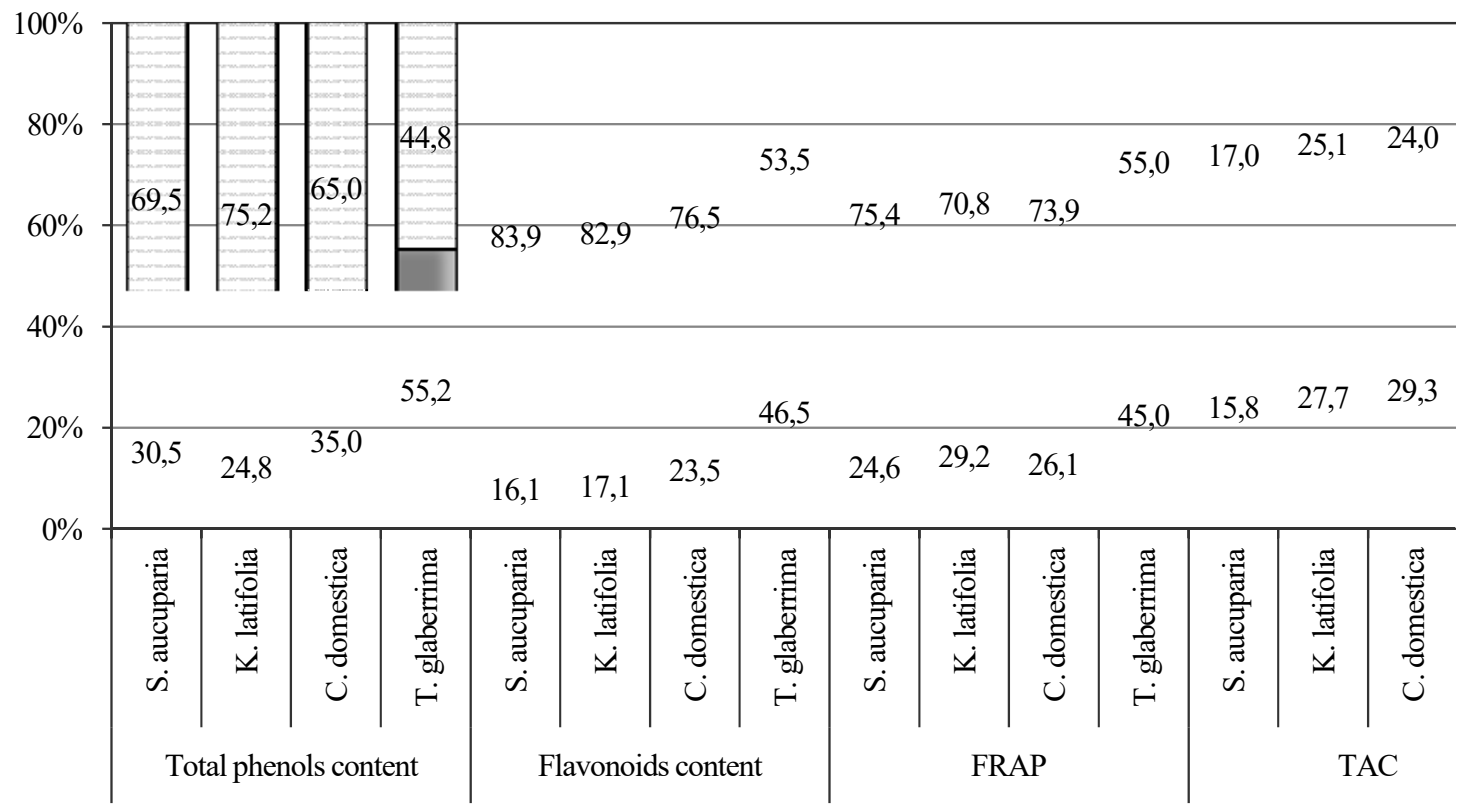

Fig. 1. The ratio of antioxidant activity indicators (TPC, TFC, $\bar{F} R \dot{P}$ and TAC) in the fruit peel and pulp of rowan and closely related species

Table 5

Statistical differences in the total (peel and pulp) phytochemical parameters of rowan (sensu lato) fruits $(\mathrm{X} \pm \mathrm{SE}, n=3, \mathrm{P}<0.05)$

\begin{tabular}{lcccc}
\hline \multicolumn{1}{c}{ Species } & TPC, $\mathrm{mg} \mathrm{GA} / 100 \mathrm{~g}$ & TFC, $\mathrm{mg} \mathrm{Ru} / 100 \mathrm{~g}$ & FRAP, mg AA/100 g & TAC, mg AA/100 g \\
\hline S. aucuparia & $520.6 \pm 8.43^{\mathrm{a}}$ & $101.36 \pm 2.01^{\mathrm{a}}$ & $744.5 \pm 8.18^{\mathrm{a}}$ & $781.2 \pm 11.31^{\mathrm{a}}$ \\
K. latifolia & $656.2 \pm 3.95^{\mathrm{b}}$ & $126.0 \pm 2.31^{\mathrm{b}}$ & $952.4 \pm 8.66^{\mathrm{b}}$ & $1239.2 \pm 32.95^{\mathrm{b}}$ \\
C. domestica & $387.5 \pm 3.08^{\mathrm{c}}$ & $76.47 \pm 2.04^{\mathrm{c}}$ & $801.9 \pm 10.92^{\mathrm{a}}$ & $1239.2 \pm 25.55^{\mathrm{b}}$ \\
T. glaberrima & $559.0 \pm 14.78^{\mathrm{a}}$ & $106.0 \pm 2.46^{\mathrm{a}}$ & $788.1 \pm 20.41^{\mathrm{a}}$ & $1476.6 \pm 9.98^{\mathrm{c}}$ \\
\hline
\end{tabular}

Note: the different letters in column indicate statistically significant differences in the means of the compared pair according to the Tukey criterion (HSD).

Correlation analysis revealed a strong positive relationship between various phytochemical parameters of rowan fruits determined in our study. In fruit pulp, high correlation coefficients were found for the following pairs: TPC and TFC $(\mathrm{r}=0.98, \mathrm{P}<0.0001)$; TPC and FRAP $(\mathrm{r}=0.87, \mathrm{P}<0.0002)$ TFC and FRAP $(r=0.91, P<0.0001)$. A similar strong correlation was found between the indicators determined in the skin of the fruit: TPC and TFC $(r=0.98, P<0.0001)$; TPC and FRAP $(\mathrm{r}=0.75, \mathrm{P}<0.0053) ;$ TFC and FRAP $(\mathrm{r}=0.75$, $\mathrm{P}<0.0054)$.
However, the correlation between TAC and all other phytochemical indicators was low both in the pulp and in the skin of the fruit, indicating that some compounds (for example, ascorbic acid) that we did not study made a large contribution to the formation of total antioxidant capacity in rowan fruits.

\section{Conclusion}

The results of a comparative phytochemical study of the fruits of rowan (Sorbus aucuparia) and closely related species 
Cormus domestica, Karpatiosorbus latifolia, and Torminalis glaberrima showed a high antioxidant potential of all studied plants. However, fruits of the species Karpatiosorbus latifolia and Torminalis glaberrima accumulated higher levels of secondary metabolites (phenolic compounds in general, as well as flavonoids) and had high antioxidant activity. On the basis of a comprehensive assessment of fruits antioxidant capacity, the species Karpatiosorbus latifolia (Lam.) Sennikov \& Kurtto and Torminalis glaberrima (Gand.) Sennikov \& Kurtto were designated as promising for the cultivation in arid climatic conditions of the steppe zone of Ukraine.

\section{References}

Bae, J. T., Sim, G. S., Kim, J. H., Pyo, H. B., Yun, J. W., \& Lee, B. C. (2007). Antioxidative activity of the hydrolytic enzyme treated Sorbus commixta Hedl. and its inhibitory effect on matrix metalloproteinase-1 in UV irradiated human dermal fibroblasts. Archives of Pharmacal Research, 30(9), 1116-1123.

Bozhuyuk, M. R., Ercisli, S., Ayed, R. B., Jurikova, T., Fidan, H., Ilhan, G., Ozkan, G., \& Sagbas, H. I. (2020). Compositional diversity in fruits of rowanberry (Sorbus aucuparia L.) genotypes originating from seeds. Genetika, 52(1), 55-65.

Burga, C. A, Bührer, S., \& Klötzli, F. (2019). Mountain ash (Sorbus aucuparia) forests of the Central and Southern Alps (Grisons and Ticino, Switzerland - Prov. VerbanoCusio-Ossola, N-Italy): Plant ecological and phytosociological aspects. Tuexenia, 39, 121-138.

Chang, S. K., Alasalvar, C., Shahidi, F. (2019). Superfruits: Phytochemicals, antioxidant efficacies, and health effects A comprehensive review. Critical Reviews in Food Science and Nutrition, 59(10), 1580-1604.

Datsko, A. M. (2004). Introduktsiya vidov roda Sorbus v Donetskiy botanicheskiy sad NAN Ukrainy [Introduction of the genus Sorbus L. species to the Donetsk Botanical Gardens]. Industrial Botany, 4, 121-124 (In Russian).

Dragonyuk, O. A., Dragonyuk, M. A., \& Marushko, L. P. (2012). Antyoksydantna diia ekstraktiv likarskykh roslyn rodyny Lamiaceae na stabilnist olii soniashnykovoi $\mathrm{v}$ protsesi zberihannia [Antioxidant effect of some plant extracts on the stability of sunflower oil during storage]. Naukovyj visnyk Volyns'koho nacional'noho universytetu imeni Lesi Ukrajinky, 17, 127-132 (In Ukrainian).

Drvodelić, D., Oršanić, M., Vuković, M., Jatoi, M. A., \& Jemrić, T. (2018). Correlation of fruit size with morphophysiological properties and germination rate of the seeds of Service Tree (Sorbus domestica L.). South-east European Forestry, 9(1), 47-54.

Feulner, M., Liede-Schumann, S., Meve, U., Weig, A., \& Aas, G. (2013). Genetic structure of three Sorbus latifolia (Lam.) Pers. taxa endemic to northern Bavaria. Plant Systematics and Evolution, 299, 1065-1074.

Gaivelyte, K., Jakstas, V., Razukas, A., \& Janulis, V. (2013). Variation in the contents of neochlorogenic acid, chlorogenic acid and three quercetin glycosides in leaves and fruits of rowan (Sorbus) species and varieties from collections in Lithuania. Natural Product Communications, $8(8), 1105-1110$.

Grynyk, I. V., Moskalets', T. Z., Frantsishko, V. S.. Moskalets', V. V., Chmyr', S. M., Lyaskovs'ky, A. A., Frantsishko, B. V., Frantsishko, V. V., \& Matlai I. Y. (2019). Checkertree mountainash (Sorbus torminalis (L.) Crantz): New breeding forms and promises of their use in horticulture. Sadivnytstvo (horticulture), 74, 45-65 (in Ukrainian).

Jin, S., Kim, K. C., Kim, J. S., Jang, K. I., \& Hyun, T. K. (2020). Anti-melanoma activities and phytochemical compositions of sorbus commixta fruit extracts. Plants (Basel), 9(9), 1076.
Kang, D. G., Lee, J. K., Choi, D. H., Sohn, E. J., Moon, M. K., \& Lee, H. S. (2005). Vascular relaxation by the methanol extract of Sorbus cortex via NO-cGMP pathway. Biological \& Pharmaceutical Bulletin, 28(5), 860-864.

Khromykh, N., Lykholat, Y., Shupranova, L., Kabar, A., Didur, O., Lykholat, T., \& Kulbachko, Y. (2018). Interspecific differences of antioxidant ability of introduced Chaenomeles species with respect to adaptation to the steppe zone conditions. Biosystems Diversity, 26(2), $132-138$

Kolupaev, Yu. E., \& Kokorev, A. I. (2019). Antioxidant system and plant resistance to water deficit. Plant Physiology And Genetics, 51(1), 28-54 (in Russian).

Lee, S. O, Lee, H. W., Lee, I. S., \& Im, H. G. (2006). The pharmacological potential of Sorbus commixta cortex on blood alcohol concentration and hepatic lipid peroxidation in acute alcohol-treated rats. Journal of Pharmacy and Pharmacology, 58(5), 685-693.

Markin, O. M., \& Krivoruchko, O. V. (2020). The determination of phenolic compounds in fruit of Sorbus aucuparia. Medical and Clinical Chemistry, 22(3), 68-73 (in Ukrainian)

Melnichenko, N. E. (1999). Introdukciya vidov roda Sorbus L. $\mathrm{v}$ Ukraine i perspektivy ih ispol'zovaniya [Introduction of species of the genus Sorbus L. in Ukraine and the prospects of its uses]. Introduktsiia roslyn (Plant Introduction), 2, 37-42 (in Russian).

Olszewska, M. A. (2011). Variation in the phenolic content and in vitro antioxidant activity of Sorbus aucuparia leaf extracts during vegetation. Acta Poloniae Pharmaceutica, 68(6), 937-944.

Olszewska, M. A., Nowak, S., Michel, P., Banaszczak, P., \& Kicel, A. (2010). Assessment of the content of phenolics and antioxidant action of inflorescences and leaves of selected species from the genus Sorbus sensu stricto. Molecules (Basel, Switzerland), 15(12), 8769-8783.

Paganová, V. (2008). Ecology and distribution of service tree Sorbus domestica (L.) in Slovakia. Ekológia (Bratislava), 27(2), 152-167.

Pękal, A., \& Pyrzynska, K. (2014). Evaluation of aluminum complexation reaction for flavonoid content assay. Food Analytical Methods, 7, 1776-1782.

Poljak, I., Kajba, D., Ljubić, I., \& Idžojtić, M. (2015). Morphological variability of leaves of Sorbus domestica L. in Croatia. Acta Societatis Botanicorum Poloniae, 84(2), 249-259.

Prieto, P., Pineda, M., \& Aguilar, M. (1999). Spectrophotometric Quantitation of antioxidant capacity through the formation of a phosphomolybdenum complex: specific application to the determination of vitamin $\mathrm{E}$. Analytical Biochemistry, 269, 337-341.

Pulido, R., Bravo, R. L., \& Saura-Calixto, F. (2000). Antioxidant activity of dietary polyphenols as determined by a modified ferric reducing/antioxidant power assay. Journal of Agricultural and Food Chemistry, 48, 3396-3402.

Raudonè, L., Raudonis, R., Gaivelyte, K., Pukalskas, A., Viškelis, P., Venskutonis, P.R., \& Janulis, V. (2015). Phytochemical and antioxidant profiles of leaves from different Sorbus L. species. Natural Products Research, 29(3), 281-285.

Raudonis, R., Raudonè, L., Gaivelyte, K., Viškelis, P., \& Janulis, V. (2014). Phenolic and antioxidant profiles of rowan (Sorbus L.) fruits. Natural Products Research, 28(16), 1231-1240.

Red data book of Ukraine. Vegetable Kingdom (2009). Ed. by Didukh Ya.P. Kyiv, Globalconsalting, 900 p. (in Ukrainian)

Rudow, A., \& Aas, G. (1997). Sorbus latifolia sl in Central Northern Switzerland: Distribution, site and population biology. Botanica Helvetica, 107(1), 51-73 (in Germanian). 
Sarv, V., Venskutonis, P. R, \& Bhat, R. (2020). The Sorbus spp.-underutilised plants for foods and nutraceuticals: $\underline{\text { Review on polyphenolic phytochemicals and antioxidant }}$ potential. Antioxidants (Basel), 9(9), 813.

Sennikov, A. N., \& Kurtto, A. (2017). A phylogenetic checklist of Sorbus s.l. (Rosaceae) in Europe. Memoranda Societatis pro Fauna et Flora Fennica, 93, 1-78.

Shaposhnik, E. I., Deineka, L. A., Sorokopudov, V. N., Deineka, V. I., Burmenko, J. V., Kartushinskiy, V. V., \& Tregubov, A. V. (2011). Biologically active substances of Ribes L. fruits. Belgorod State University Scientific Bulletin. Natural sciences, 9(104) (15/2), 238-248 (in Russian).

Singleton, V. L., Orthofer, R., \& Lamuela-Raventos, R. M. (1999). Analysis of total phenols and other oxidation substrates and antioxidants by means of Folin-Ciocalteau reagent. Methods in Enzymology, 299, 152-178.

Sohn, E. J., Kang, D. G., Choi, D. H., Lee, A. S., Mun, Y. J., Woo, W. H., Kim, J. S., \& Lee, H. S. (2005a). Effect of methanol extract of Sorbus cortex in a rat model of L-NAME-induced atherosclerosis. Biological \& Pharmaceutical Bulletin, 28(7), 1239-1243.

Sohn, E. J., Kang, D. G., Mun, Y. J., Woo, W. H., \& Lee, H. S. (2005b). Anti-atherogenic effects of the methanol extract of Sorbus cortex in atherogenic-diet rats. Biological \& Pharmaceutical Bulletin, 28, 1444-1449.

Soltys, A., Galanty, A. \& Podolak, I. (2020). Ethnopharmacologically important but underestimated genus Sorbus: a comprehensive review. Phytochemistry Reviews, 19, 491-526.

Thomas, P. A. (2017). Biological Flora of the British Isles: Sorbus torminalis. Journal of Ecology, 105, 1806-1831.
Tomović, G., Sabovljević, M. S., Djokić, I., Petrović, P., Djordjević, V., Lazarević, P., Mašić, E., Barudanović, S. Stefănut, S., Niketić, M., Butorac, B., Pantović, J., Hajrudinović-Bogunić, A., Bogunić, F., Kabaš, E., Vukojičić, S., Kuzmanović, N., Djurović, S. Z., \& Buzurović, U. (2020). New records and noteworthy data of plants, algae and fungi in SE Europe and adjacent regions, 2. Botanica Serbica, 44(2), 251-259.

Welk, E., de Rigo, D., Caudullo, G. (2016). Sorbus aria in Europe: distribution, habitat, usage and threats. In: SanMiguel-Ayanz, J., de Rigo, D., Caudullo, G., Houston Durrant, T., Mauri, A. (Eds.), European Atlas of Forest Tree Species. Publ. Off. EU, Luxembourg, e01e816

Yin, M. H., Kang, D. G., Choi, D. H., Kwon, T. O., \& Lee, H. S. (2005). Screening of vasorelaxant activity of some medicinal plants used in Oriental medicines. Journal of Ethnopharmacology, 99(1), 113-117.

Yu, T., Lee, Y. J., \& Cho, J. Y. (2009). Inhibitory effect of Sorbus commixta extract on lipopolysaccharide-induced pro-inflammatory events in macrophages. Journal of Medicinal Plants Research, 3(8), 600-607.

Yu, T., Lee, Y. J., Jang, H. J., Kim, A. R., Hong, S., Kim, T. W., Kim, M. Y., Lee, J., Lee, Y. G., \& Cho, J. Y. (2011). Antiinflammatory activity of Sorbus commixta water extract and its molecular inhibitory mechanism. Journal of Ethnopharmacology, 134(2), 493-500.

Zieliński, J., \& Vladimirov, V. (2013). Sorbus $\times$ latifolia s.l. (Rosaceae) in the Balkan Peninsula and SW Asia. Phytologia Balcanica, 19(1), 39-46.

Zymone, K., Raudone, L., Raudonis, R., Marksa, M., Ivanauskas, L., \& Janulis, V. (2018). Phytochemical profiling of fruit powders of twenty Sorbus L. cultivars. Molecules, 23(10), 2593. 